\title{
Evaluation the Use of Distance Learning in Jordanian Universities during the COVID19 Pandemic.
}

\author{
Fadi Abdul Raheem Odeh Bani Ahmad Bani \\ Middle East University. \\ Faculty of Educational Sciences \\ Amman, Jordan \\ Fodah@meu.edu.jo
}

Article History: Received: 10 November 2020; Revised 12 January 2021 Accepted: 27 January

2021; Published online: 5 April 2021

\begin{abstract}
Various countries have shifted from face-to-face learning to distance learning in response to the challenges imposed by the spread of the COVID19. Worldwide distance learning has become a global phenomenon. The current study aims to evaluate the use of distance learning in Jordanian universities during the covid19 pandemic. The study has developed standards for using distance learning in Jordanian universities and the current status of using distance learning in Jordanian universities. To achieve these aims, the descriptive approach is adopted. A list of the necessary standards for using distance learning is developed, and the current status of using distance learning in Jordanian universities is determined through five domains, and descriptive statistics (means and standard deviations) were calculated as well. The results show the weakness of the technological and human infrastructure necessary for distance learning, and its low ability to create an attractive educational environment, making the use of technology a_formal matter that does not achieve the slightest added value to the educational process, along with the weak evaluation of the quality of electronic content. Therefore, the study recommends the necessity of providing modern technological and human infrastructure for higher education institutions to activate them neatly to support the continuity of the educational process.
\end{abstract}

Keywords: Evaluation, Higher education institutions, Distance Learning, COVID19.

\section{Introduction}

The whole world communities today face COVID-19 which is a pandemic crisis affecting all aspects of human life. COVID-19 is described by the World Health Organization (WHO) as a global pandemic that invades space and time, attacks societies in their essence, and causes economic, social, financial, and political crises in today's world (Rieley, J. B, 2020). COVID-19 also causes the closure and lockdown of most educational institutions in the world to find options to deal with this challenging situation to reduce the rate of transmission and occurrence of infection and disease (Anderson et al., 2020). Besides, COVID-19 is first recognized in November 2019 in Wuhan City, China, and has since spread globally resulting in the current 2019-2020 coronavirus pandemic (Hui, et al., 2020). Infection of COVID-19 causes severe acute respiratory syndrome virus 2 (SARS-CoV-2) (Wenham et al.2020) and it spreads through sneezing, coughing, or talking and can live for long hours on many surfaces, so the World Health Organization has called it the global pandemic (Dun \& Bradstree, 2020).

Developing countries are at a low level of competence and preparedness towards the orientation of distance learning, which leads to concern about the issue of education even before the COVID-19 pandemic. At the individual and collective situation and level, students and faculty members face many challenges and obstacles that limit distance learning (Thurman, A. (2019). However, Rani Molla (2020) asserts that the problem lies in the lack of infrastructure necessary for distance learning, requiring the elements of the educational process to use the available facilities, which reduces the opportunities for effective distance learning. Distance learning requires the provision of learning platforms that shall be continuously evaluated to achieve educational outcomes through multimedia, which requires the availability of a good internet connection (Basilaia et al., 2020).

\section{Statement of the problem}

Without prior warning, higher education institutions in Jordan found themselves in a race against time to shift to a distance learning model imposed by the current circumstances as a result of the COVID19. These 
institutions have initially responded disproportionately and satisfactorily to this challenge, but the need has become urgent to reconsider the evaluation of distance learning to ensure its quality in facing challenges and contributing to improving the quality of higher education in Jordan. In light of this, the problem of the study emerging from the researcher's work and practice of distance learning and during the second semester of the academic year 2019/2020 A preliminary analysis of the emergent learning process outcomes shows that there are many problems related to distance learning including the weak homogeneity and disparity in student satisfaction levels with distance learning, the low academic follow-up, and the slow Internet connection. Importantly, the recommendations of recent studies, (Mundy \& Hares, 2020), as well as the ten recommendations referred to by the UNESCO report that closing educational institutions harm millions of students in around the world (UNESCO. 2020). Andreas, Nusrat, and Goldin (2020) reported that this virus is in most cases remains for a longer period than expected and must be coexisting with it and confirm the necessity that the virus shall not hinder the progress of the education process. Thus, the process of using distance learning shall be evaluated on an ongoing basis.

\section{Questions of the study}

In light of the problem of the study, the following questions are formatted.

1. What are the standards for using distance learning in Higher education institutions?

2. What is the reality of using distance learning in Higher education institutions?

\section{Objectives of the study}

The current study aims to evaluate the use of distance learning in higher education in Jordan in light of the global spread of the COVID19 pandemic. The study will define the standards for using distance learning in higher education institutions through identifying the standards for using distance learning in higher education and the reality of using distance learning.

\section{The Significance of the study}

In light of the originality and novelty of the problem addressed in the study, the significance of this study appears in theoretical and practical aspects. The theoretical aspect shows that the study seeks to evaluate the use of distance learning in higher education in Jordan in light of the global spread of the COVID19, which provides an important indicator for examining the first experience in higher education through distance learning. Also, it is the first study in the Jordanian educational environment addressing this key topic due to the novelty of this experience, as the COVID19 pandemic surprises countries and imposes challenges on them without previous notice or announcement. From the practical side, this research is recognized in giving feedback to decisionmakers in higher education institutions in deciding on the appropriateness of using distance learning in Higher education institutions and working to identify strengths to strengthen them and identify weaknesses so that a novel plan can be developed to improve the distance learning process and thus provide the recommendations based on the results of the study.

\section{Theoretical framework}

Social distancing is regarded as the main tool and base necessary for the individual's survival skills. The social development of the learner is negatively affected by the lack of communication and interaction among students and community members. As a result of the spread of the COVID19, distance learning has replaced traditional learning (O'Sullivan, 2017, Krewer, \& Frank). Researchers (Essaid El Bachari et al., (2011) believe that distance learning is effective for all and consuders the characteristics and needs of learners. Also, Hannay and Newvine (2006) confirm that distance learning provides an opportunity for learning throughout time and anywhere. Visande (2014) indicates that through distance learning, learning outcomes are achieved to a high extent and the impact of learning outcomes remains for a longer period of time because it provides scientific content in more than one way and style.

Distance learning improves the educational practices of the learners, as the study (Tran, Trung; Hoang, AnhDuc, 2020) proved that it puts a future vision on how to advance learning and achieve sustainable development 4 (SDG4). Likewise, Rao (2011) confirms that distance learning has become a global phenomenon, tremendously contributing to the development of education. 
Due to the significance of distance learning, numerous studies are conducted, including a study by Basilaia \& Kvavadze (2020), which investigated the level of schools' capabilities to continue the educational process in distance learning after the COVID19 pandemic through Microsoft Teams, where the case study used is 950school students in Georgia. The results confirmed the success of the rapid transition to distance learning. However, traditional learning remains more effective as the current educational curricula are not designed for distance learning. Another study by Fojtik, (2018) investigated the effectiveness of distance learning compared to traditional learning in the Czech Republic, and the study showed statistically significant differences among students due to the type of learning in favor of traditional learning versus distance learning due to the low preparedness of technological infrastructure in educational institutions.

In light of the previous review, it appears that distance learning faces problems related to digital content, the infrastructure, and the competencies of teachers to implement this type of learning along with the economic cost, especially in developing countries. The current study is a vital addition to previous studies in evaluating the use of distance learning in higher education and the extent of the application of quality standards on it. Distance learning needs pre-preparation and qualification for the educational staff and in this context. McPhee, (2012) indicates that this type of learning requires the preparation of high-quality educational materials, and students need to follow their learning process in an organized and continuous manner, but the majority of students follow it at the end of the semester, which will be reflected in their academic performance. Therefore, some studies emphasize technical qualification and training of teachers including the study by Klimova (2015) that confirms that the basic problem of distance learning lies in the availability of sufficient and adequate technical expertise for both parties to the learning process. Importantly, distance learning enhances the learner's feeling about learning and education, and also makes him/her feel equal learning opportunities. Warrier (2006) maintains that one of the most important justifications for distance learning is that distance learning breaks the barriers of fear and anxiety among students, and enables the learner to express his opinion as the learner finds it easy to access the teacher even outside the official working hours.

\section{Limitations of the study}

This study is limited to evaluate the use of distance learning in universities in Jordan in light of the global spread of the COVID19 pandemic. It is also limited to a random sample of public universities in Jordan. Moreover, it is applied in the academic year 2019/2002.

\section{Methodology of the study}

In light of the objectives and nature of the study, the descriptive approach is used as it is the appropriate scientific approach to the problem of the study, its objectives, and its conclusions.

\section{- $\quad$ Population and sample study}

The population and sample study composed of all faculty members of the Faculties of Education in three universities in Jordan (Yarmouk University, University of Jordan, and the Middle East University). A simple random sample was selected by the method of (cards/lottery), so the study sample consists of (3) universities, and included (65) faculty members from the Faculties of Education. Table (1) shows the names of the universities of the study sample and the number of faculty members at the Faculty of Education for each university.

Table 1: The names of the universities of the study sample and the number of faculty members

\begin{tabular}{ccc}
\hline No. Item & Name of University & Number of Faculty Members. \\
\hline $\mathbf{1}$ & Yarmouk University & 25 \\
\hline $\mathbf{2}$ & University of Jordan & 25 \\
\hline $\mathbf{3}$ & Middle East University & 15 \\
\hline & Total & 65 \\
\hline
\end{tabular}

\section{- Instruments}

The study used to instruments, the first instrument is a list of standards for using distance learning in Higher education institutions. Its purpose is to define the standards for using distance learning in Higher education institutions. The instrument's reliability is calculated using an internal consistency method using Cronbach's alpha equation, which is (82.9). 
The second was a five points Likert-style survey that is developed to determine the use of distance learning during the COVID19 pandemic in higher education institutions. The scale ranging from (1) Strongly Agree to (5) Strongly Disagree.

\section{Results}

This section presents the results and the answers to the two questions of the study.

First: Answer to the first question "What are the standards for using distance learning in Higher education institutions?"

To answer the first question, a list of standards for using distance learning in Higher education institutions is prepared. Table (3) shows a matrix for the final list of standards for using distance learning in Higher education institutions.

Table 2: Matrix of the list of the standards for using distance learning in Higher education institutions.

\begin{tabular}{|c|c|c|c|}
\hline Domains & Standards & $\begin{array}{l}\text { Reference } \\
\text { Numbers }\end{array}$ & Indicators \\
\hline \multirow[t]{4}{*}{$\begin{array}{l}\text { First Domain: } \\
\text { Technological } \\
\text { Structure }\end{array}$} & $\begin{array}{l}\text { 1- The university is characterized by a } \\
\text { technological infrastructure suitable for } \\
\text { the distance learning system. }\end{array}$ & 2 & 5 \\
\hline & $\begin{array}{l}\text { 2- The university provides mechanisms } \\
\text { for transforming electronic content to } \\
\text { learners. }\end{array}$ & 2 & 7 \\
\hline & $\begin{array}{l}\text { 3- The university has technical and } \\
\text { technological support for distance } \\
\text { learning. }\end{array}$ & 2 & 4 \\
\hline & $\begin{array}{l}\text { 4- The university is keen to strengthen } \\
\text { the technological infrastructure. }\end{array}$ & 2 & 7 \\
\hline \multirow[t]{5}{*}{$\begin{array}{l}\text { Second Domain: } \\
\text { Electronic } \\
\text { Content }\end{array}$} & $\begin{array}{l}\text { 1- The university takes into account the } \\
\text { relevance of the educational content to } \\
\text { the students' developmental } \\
\text { characteristics. }\end{array}$ & 2 & 6 \\
\hline & $\begin{array}{l}\text { 2- The university designs distance } \\
\text { learning resources. }\end{array}$ & 3 & 6 \\
\hline & $\begin{array}{l}\text { 3- The university produces distance } \\
\text { learning resources. }\end{array}$ & 2 & 6 \\
\hline & $\begin{array}{l}\text { 4- The university evaluates the quality of } \\
\text { electronic content within the distance } \\
\text { learning system. }\end{array}$ & 2 & 7 \\
\hline & $\begin{array}{l}\text { 5- The university publishes the electronic } \\
\text { system, and uses it in the educational } \\
\text { process. }\end{array}$ & 2 & 6 \\
\hline \multirow[t]{6}{*}{$\begin{array}{l}\text { Third Domain: } \\
\text { Faculty Member }\end{array}$} & $\begin{array}{l}\text { 1- The faculty member determines the } \\
\text { students' needs in distance learning. }\end{array}$ & 2 & 5 \\
\hline & $\begin{array}{l}\text { 2- The faculty member designs distance } \\
\text { learning strategies and activities. }\end{array}$ & 2 & 7 \\
\hline & $\begin{array}{l}\text { 3- The faculty member creates an } \\
\text { appropriate electronic environment that } \\
\text { takes into account the intended learning } \\
\text { outcomes. }\end{array}$ & 2 & 4 \\
\hline & $\begin{array}{l}\text { 4- The faculty member is keen on having } \\
\text { professional development programs for } \\
\text { the distance learning system. }\end{array}$ & 2 & 8 \\
\hline & $\begin{array}{l}\text { 5- The faculty member carries out self- } \\
\text { evaluation and feedback in the distance } \\
\text { learning system. }\end{array}$ & 2 & 6 \\
\hline & $\begin{array}{l}\text { 6- The faculty member abides by } \\
\text { distance learning controls. }\end{array}$ & 2 & 8 \\
\hline Fourth Domain: & 1 - The learner has the skills to interact & 2 & 8 \\
\hline
\end{tabular}




\begin{tabular}{|c|c|c|c|}
\hline \multirow[t]{3}{*}{ Learner } & \multicolumn{3}{|l|}{ with distance learning. } \\
\hline & $\begin{array}{l}\text { 2- The learner is proficient in using } \\
\text { information and communication } \\
\text { technology for the distance learning } \\
\text { system. }\end{array}$ & 2 & 5 \\
\hline & $\begin{array}{l}\text { 3- The learner shall abide by the controls } \\
\text { of using the distance learning system. }\end{array}$ & 2 & 4 \\
\hline \multirow[t]{2}{*}{$\begin{array}{l}\text { Fifth Domain: } \\
\text { Evaluation }\end{array}$} & $\begin{array}{l}\text { 1- The university takes into account the } \\
\text { foundations of evaluating the elements of } \\
\text { the distance learning system. }\end{array}$ & 2 & 7 \\
\hline & $\begin{array}{l}\text { 2- The university provides procedures for } \\
\text { evaluating the distance learning system. }\end{array}$ & 3 & 15 \\
\hline Total & 20 & 42 & 129 \\
\hline
\end{tabular}

Thus, the first question of the study's questions is answered, which reads "What are the standards for using distance learning in Higher education institutions?"

\section{Second: Answer to the second question "What is the reality of using distance learning in Higher education institutions?"}

To answer the second question, the study sample and the arithmetic means, and standard deviations of the responses of the study sample individuals are calculated, and they are arranged in descending order according to the arithmetic means of the indicators for each domain, as shown in Table (4).

First Domain: Technological Structure

Table 3: The means and standards deviation of the study sample responses on the first domain: the technological structure (indicators 1: 23).

\begin{tabular}{|c|c|c|c|c|}
\hline No. & Indicator & M & SD & $\begin{array}{l}\text { Degree of } \\
\text { availability } \\
\text { of the } \\
\text { indicator }\end{array}$ \\
\hline 1 & $\begin{array}{l}\text { 1-3-1-1 The educational university has qualified } \\
\text { human resources to pursue the technological } \\
\text { infrastructure. }\end{array}$ & 2.95 & 229. & Medium \\
\hline 2 & $\begin{array}{l}\text { 1-1-1-2 The university is linked to the video } \\
\text { conference network of the Directorate for the use } \\
\text { of distance learning. }\end{array}$ & 2.69 & 635. & Medium \\
\hline 3 & $\begin{array}{l}\text { 1-1-2-1 The university has laboratories equipped } \\
\text { with modern computers. }\end{array}$ & 2.62 & 593. & Medium \\
\hline 4 & $\begin{array}{l}\text { 1-1-1-1 The university has equipment and systems } \\
\text { for virtual classes. }\end{array}$ & 2.60 & 596. & Low \\
\hline 5 & 1-2-1-4 The university has a website. & 2.49 & 573. & Low \\
\hline 6 & $\begin{array}{l}\text { 1-3-1-2 The university provides teacher training } \\
\text { programs on the distance learning system. }\end{array}$ & 2.42 & 567. & Low \\
\hline 7 & $\begin{array}{l}\text { 1-2-2-1 The university determines the mechanisms } \\
\text { for documenting electronic content. }\end{array}$ & 2.38 & 490. & Low \\
\hline 8 & $\begin{array}{l}\text { 1-1-2-2 The university provides the necessary } \\
\text { internet service for distance learning and } \\
\text { education. }\end{array}$ & 2.25 & 775. & Low \\
\hline 9 & $\begin{array}{l}\text { 1-3-2-2 The university sets a periodic plan for } \\
\text { maintaining the technological infrastructure. }\end{array}$ & 2.18 & 547. & Low \\
\hline 10 & $\begin{array}{l}\text { 1-3-2-1 The university provides the necessary } \\
\text { technical support for networks and computers. }\end{array}$ & 2.11 & 567. & Low \\
\hline 11 & $\begin{array}{l}\text { 1-2-2-2 The university controls the management } \\
\text { of all distance learning processes. }\end{array}$ & 2.09 & 482. & Low \\
\hline 12 & 1-2-1-3 The university uses software that supports & 2.07 & 539. & Low \\
\hline
\end{tabular}




\begin{tabular}{|c|c|c|c|c|}
\hline 13 & $\begin{array}{l}\text { the use of various styles of distance learning. } \\
1-4-2-3 \text { The university takes into account the } \\
\text { needs of students and the privacy of society and its } \\
\text { values when applying the experiences of the } \\
\text { corresponding institutions. }\end{array}$ & 2.05 & 524. & Low \\
\hline 14 & $\begin{array}{l}\text { 1-4-1-4 The university provides courses to train } \\
\text { faculty members to use modern technology. }\end{array}$ & 2.04 & 576. & Low \\
\hline 15 & $\begin{array}{l}\text { 1-2-1-2 The university determines, through its } \\
\text { website, how to receive students. }\end{array}$ & 2.04 & 508. & Low \\
\hline 16 & $\begin{array}{l}\text { 1-4-1-1 The university is preparing a plan to } \\
\text { update the technological infrastructure for distance } \\
\text { learning. }\end{array}$ & 2.02 & 304. & Low \\
\hline 17 & $\begin{array}{l}\text { 1-2-1-1 The educational institution publishes } \\
\text { electronic courses through its website. }\end{array}$ & 2.00 & 770 . & Low \\
\hline 18 & $\begin{array}{l}\text { 1-4-2-1 The university sets a plan for cooperation } \\
\text { with counterpart institutions in distance learning } \\
\text { processes. }\end{array}$ & 1.96 & 356. & Low \\
\hline 19 & $\begin{array}{l}1-2-2-3 \text { The university modifies the procedures of } \\
\text { distance learning management processes in light } \\
\text { of the evaluation results. }\end{array}$ & 1.95 & 356. & Low \\
\hline 20 & $\begin{array}{l}\text { 1-1-2-3 The university commits to a plan to } \\
\text { operate laboratories according to distance learning } \\
\text { programs. }\end{array}$ & 1.95 & 621. & Low \\
\hline 21 & $\begin{array}{l}\text { 1-4-2-2 The university benefits from cooperation } \\
\text { with counterpart institutions in distance learning } \\
\text { operations. }\end{array}$ & 1.93 & 424. & Low \\
\hline 22 & $\begin{array}{l}\text { 1-4-1-3 The university adheres to a teacher } \\
\text { training plan. }\end{array}$ & 1.93 & 424. & Low \\
\hline 23 & $\begin{array}{l}\text { 2- The university provides funding sources for } \\
\text { modernizing the technological infrastructure for } \\
\text { distance learning. }\end{array}$ & 1.87 & 640. & Low \\
\hline
\end{tabular}

The results of Table (3) indicate the existence of qualified human resources and their suitability for teaching and distance learning, the link of the educational institution to the video network, and the availability of equipment and systems for virtual classes at the university are of a medium degree. The scores' mean of the sample members ranges between (2.95) and (2.65), while the indicators' score is in the ranking from (4:23) (weak) where their mean is between (2.60) and (1.87).

\section{Second Domain: Electronic Content}

Table 4

The means and standard deviations of the study sample responses on the second domain: electronic content (indicators 24:54).

\begin{tabular}{|c|c|c|c|c|}
\hline No. & Indicator Text & $\mathbf{A M}$ & SD & $\begin{array}{ll}\text { Degree } & \text { of } \\
\text { availability } & \text { of } \\
\text { the indicator } & \end{array}$ \\
\hline 24 & $\begin{array}{l}\text { 2-1-1-3 The educational designer is committed to } \\
\text { the developmental characteristics of learners } \\
\text { when determining educational content. }\end{array}$ & 2.69 & 466. & Medium \\
\hline 25 & $\begin{array}{l}\text { 2-1-2-2 The university takes into account the } \\
\text { intended learning outcomes in the electronic } \\
\text { content. }\end{array}$ & 2.16 & 462. & Weak \\
\hline 26 & $\begin{array}{l}2-2-2-2 \text { The university proposes electronic } \\
\text { content activities appropriate to the targeted } \\
\text { learning outcomes. }\end{array}$ & 2.09 & 482. & Weak \\
\hline 27 & $\begin{array}{l}\text { 2-1-1-1 The university determines the } \\
\text { developmental characteristics of students. }\end{array}$ & 2.09 & 617. & Weak \\
\hline 28 & $\begin{array}{l}2-4-2-4 \text { The university provides feedback on the } \\
\text { processes of measuring student achievement rates. }\end{array}$ & 2.07 & 378. & Weak \\
\hline
\end{tabular}


29 2-5-1-2 The university works to secure the information of the faculty member within the distance learning system.

30 2-3-2-2-2 The university uses various methods of $2.04 \quad 383$. Weak interaction between the elements of the distance learning system.

31 1-2-1-2-2 The university analyzes educational 2.04 331. Weak problems in light of the current situation.

32 2-5-1-1 The university is interested in spreading $2.00 \quad 272$ Weak the education and distance learning system to those concerned.

33 2-4-2-3 The university prepares various 2.00 272. Weak mechanisms for measuring student achievement rates.

34 2-4-1-3 The electronic content has basic attractive $2.00 \quad 272$. Weak elements such as (video, animation)

35 2-4-2-1 The university links all parts of the 1.98 304. Weak electronic content with multiple links.

36 2-1-1-2 The university takes into account the 1.96508 . Weak needs and interests of students when determining the electronic content.

37 2-4-1-1 The university uses electronic content that $1.95 \quad 356 . \quad$ Weak is constantly updated.

$38 \quad 2-2-2-1$ The university determines the multimedia 1.95 448. Weak necessary for the distance learning system.

39 2-3-1-3 The university carries out periodic 1.93 466. Weak follow-up and evaluation of the electronic content production process.

40 1-2-1-1 The university determines the appropriate $1.91 \quad 442$. Weak electronic educational content for learners.

41 2-1-2-2 The university takes into account the 1.91554 Weak needs of students in light of the results of the analysis of educational problems.

42 2-4-2-2 The university defines the activities that 1.84 462. Weak the learner will perform.

43 1-2-3-2 The university sets clear procedural plans $1.84 \quad 501$. Weak for implementing electronic content.

44 2-3-1-1 The university defines clear procedures 1.76 508. Very weak for producing distance learning system resources.

45 2-1-2-3 The university provides the necessary 1.71 533. Very weak resources for the distance learning system.

46 2-5-1-3 The university takes into account the 1.64 557. Very weak intellectual property rights of the distance learning system.

47 2-4-1-2 The university adheres to the standard $1.60 \quad 564 . \quad$ Very weak standards for the production of electronic content.

$48 \quad 2-3-2-2$ The university provides various links that $1.56 \quad 631$. Very weak allow connection to the content.

49 2-3-1-2 The university sets a procedural plan to $1.56 \quad 631 . \quad$ Very weak implement the e-content production strategy.

50 2-5-2-2 The university prepares programs to train 1.49 573. Very weak human resources to follow the quality of distance learning.

$51 \quad 2-5-2-1$ The university sets a plan for monitoring $1.44 \quad 601 . \quad$ Very weak the quality of performance in distance learning.

$52 \quad 2$ 2-5-2-3 The university verifies the validity of 1.38 593. Very weak the distance learning content system links.

53 2-3-2-1 The university defines various tools for 1.38 561. Very weak interaction in distance learning. 


$\begin{array}{lllllll}54 & 2-3-2-3 \quad \text { The university prepares various } & 1.35 & 552 . & \text { Very weak } \\ \text { communications to suit the students } & & & \\ \text { 'circumstances. }\end{array}$

The results of Table (4) for the indicator in the ranking (24) indicate that the educational designer's commitment to the developmental characteristics of learners when determining the educational content is of a medium degree, where the scores' mean of the sample members reaches (2.69). However, the indicators' score in the ranking from (54:44) is very weak, where their mean is between (1.76) and (1.35). Therefore, the previous results reveal the weakness of defining the specifications of displaying electronic content appropriate to the developmental characteristics of learners and evaluating the quality of electronic content.

Third Domain: Faculty Member

Table 5: The arithmetic mean and standard deviation of the study sample responses on the third domain: faculty member (indicators 92:55).

\begin{tabular}{|c|c|c|c|c|}
\hline No. & Indicator Text & $\mathbf{A M}$ & SD & $\begin{array}{l}\text { Degree } \\
\text { availability } \\
\text { the indicator }\end{array}$ \\
\hline 55 & $\begin{array}{l}3-5-2-2 \text { The faculty member diversifies the } \\
\text { types of questions through the learners' } \\
\text { feedback. }\end{array}$ & 2.69 & 466. & Medium \\
\hline 56 & $\begin{array}{l}\text { 3-3-1-2 The faculty member interacts with } \\
\text { students in the distance learning } \\
\text { environment. }\end{array}$ & 2.56 & 601. & Weak \\
\hline 57 & $\begin{array}{l}\text { 3-6-1-1 The faculty member motivates } \\
\text { students to participate in setting evaluation } \\
\text { rules. }\end{array}$ & 2.51 & 717. & Weak \\
\hline 58 & $\begin{array}{l}\text { 3-4-2-1 The faculty member is fluent in } \\
\text { using distance learning tools. }\end{array}$ & 2.33 & 546. & Weak \\
\hline 59 & $\begin{array}{l}3-4-2-4 \text { The faculty member takes into } \\
\text { account the use of modern search engines in } \\
\text { the educational process. }\end{array}$ & 2.29 & 458. & Weak \\
\hline 60 & $\begin{array}{l}3-2-2-3 \text { A faculty member encourages } \\
\text { students to interact with their colleagues } \\
\text { through the institution's website. }\end{array}$ & 2.25 & 517. & Weak \\
\hline 61 & $\begin{array}{l}3-5-1-1 \text { The faculty member seeks to seek } \\
\text { the opinion of the faculty member regarding } \\
\text { his performance. }\end{array}$ & 2.24 & 508. & Weak \\
\hline 62 & $\begin{array}{l}3-4-2-2 \text { The faculty member can manage } \\
\text { learning resources in the distance learning } \\
\text { system. }\end{array}$ & 2.24 & 429. & Weak \\
\hline 63 & $\begin{array}{l}\text { 3-4-2-5 The faculty member knows multiple } \\
\text { educational sites related to educational } \\
\text { content. }\end{array}$ & 2.22 & 498. & Weak \\
\hline 64 & $\begin{array}{l}3-5-1-2 \text { The faculty member documents the } \\
\text { students' opinions in it through an } \\
\text { appropriate opinion questionnaire. }\end{array}$ & 2.20 & 404. & Weak \\
\hline 65 & $\begin{array}{l}3-4-1-2 \text { The faculty member follows up } \\
\text { development programs in using technology } \\
\text { in education. }\end{array}$ & 2.16 & 462. & Weak \\
\hline 66 & $\begin{array}{l}3-2-2-2 \text { The faculty member publishes the } \\
\text { educational activities on the Internet. }\end{array}$ & 2.16 & 536. & Weak \\
\hline 67 & $\begin{array}{l}3-5-1-3 \text { The faculty member adjusts his } \\
\text { educational performance according to the } \\
\text { results of the students' opinions analysis. }\end{array}$ & 2.15 & 524. & Weak \\
\hline 68 & $\begin{array}{l}\text { 3-4-1-3 The faculty member participates in } \\
\text { training programs related to e-learning } \\
\text { systems. }\end{array}$ & 2.15 & 488. & Weak \\
\hline 69 & 3-6-2-1 The faculty member avoids using & 2.11 & 416. & Weak \\
\hline
\end{tabular}




\begin{tabular}{|c|c|c|c|c|}
\hline & $\begin{array}{l}\text { any means indicating discrimination } \\
\text { between students }\end{array}$ & & & \\
\hline 70 & $\begin{array}{l}3-2-2-1 \text { The faculty member encourages } \\
\text { students to communicate within the distance } \\
\text { learning system. }\end{array}$ & 2.11 & 497. & Weak \\
\hline 71 & $\begin{array}{l}3-5-2-1 \text { The faculty member provides } \\
\text { feedback to learners in the distance learning } \\
\text { system. }\end{array}$ & 2.09 & 398. & Weak \\
\hline 72 & $\begin{array}{l}3-4-2-3 \text { The faculty member uses the } \\
\text { educational sites in the educational process. }\end{array}$ & 2.04 & 508. & Weak \\
\hline 73 & $\begin{array}{l}\text { 3-1-2-1 The faculty member follows up on } \\
\text { the learner's performance in the distance } \\
\text { learning system. }\end{array}$ & 2.04 & 331. & Weak \\
\hline 74 & $\begin{array}{l}\text { 3-6-1-4 The faculty member explains the } \\
\text { legal aspects of the distance learning system. }\end{array}$ & 2.00 & 430. & Weak \\
\hline 75 & $\begin{array}{l}3-2-2-1 \text { The faculty member devises various } \\
\text { activities that develop students' thinking } \\
\text { skills. }\end{array}$ & 2.00 & 544. & Weak \\
\hline 76 & $\begin{array}{l}3-6-2-2 \text { The faculty member is able to } \\
\text { efficiently manage the interaction between } \\
\text { students. }\end{array}$ & 1.98 & 451. & Weak \\
\hline 77 & $\begin{array}{l}3-6-1-3 \text { The faculty member and students } \\
\text { shall be involved in setting the rules for } \\
\text { dealing between them. }\end{array}$ & 1.98 & 304. & Weak \\
\hline 78 & $\begin{array}{l}2-3-2-2 \text { The faculty member is keen to } \\
\text { follow up the interactive communication } \\
\text { between students. }\end{array}$ & 1.98 & 561. & Weak \\
\hline 79 & $\begin{array}{l}\text { 3-1-1-2 The faculty member takes into } \\
\text { account the developmental characteristics of } \\
\text { the learner. }\end{array}$ & 1.96 & 383. & Weak \\
\hline 80 & $\begin{array}{l}3-6-2-4 \text { The faculty member is keen to } \\
\text { respect students' privacy. }\end{array}$ & 1.95 & 229. & Weak \\
\hline 81 & $\begin{array}{l}3-3-1-1 \text { The faculty member provides } \\
\text { interactive communications in the distance } \\
\text { learning environment. }\end{array}$ & 1.91 & 554. & Weak \\
\hline 82 & $\begin{array}{l}3-2-1-3 \text { The faculty member plans to } \\
\text { practically use distance learning strategies. }\end{array}$ & 1.89 & 416. & Weak \\
\hline 83 & $\begin{array}{l}3-1-2-2 \text { The faculty member identifies } \\
\text { students' problems. }\end{array}$ & 1.82 & 547. & Weak \\
\hline 84 & $\begin{array}{l}3-5-2-3 \text { The faculty member benefits from } \\
\text { the feedback regarding the course. }\end{array}$ & 1.76 & 576. & Very week \\
\hline 85 & $\begin{array}{l}\text { 3-2-1-4 The faculty member follows up on } \\
\text { students 'use of distance learning strategies. }\end{array}$ & 1.67 & 771. & Very week \\
\hline 86 & $\begin{array}{l}3-2-1-1 \text { The faculty member selects the } \\
\text { appropriate strategies for learning. }\end{array}$ & 1.65 & 552. & Very week \\
\hline 87 & $\begin{array}{l}3-4-1-1 \text { The faculty member evaluates his } \\
\text { performance periodically. }\end{array}$ & 1.64 & 677. & Very week \\
\hline 88 & $\begin{array}{l}3-1-1-1 \text { The faculty member suggests } \\
\text { requirements for achieving the educational } \\
\text { process objectives. }\end{array}$ & 1.58 & 567. & Very week \\
\hline 89 & $\begin{array}{l}3-6-1-2 \text { The faculty member determines the } \\
\text { interaction behaviors within the distance } \\
\text { learning system. }\end{array}$ & 1.55 & 633. & Very week \\
\hline 90 & $\begin{array}{l}3-2-1-2 \text { The faculty member determines the } \\
\text { special work rules within the distance } \\
\text { learning system. }\end{array}$ & 1.51 & 573. & Very week \\
\hline 91 & $\begin{array}{l}\text { 3-6-2-3 A faculty member gives students the } \\
\text { opportunity to express their views in a } \\
\text { democratic atmosphere. }\end{array}$ & 1.42 & 599. & Very week \\
\hline
\end{tabular}


$92 \quad 3-1-2-3$ A faculty member suggests solutions $1.24 \quad 508 . \quad$ Very week

to students' problems

The results of Table (5) indicate that the responses' mean of the respondents to the indicators is weak, with a mean of between (2.56) and (1.82). The results reflect a weakness in the knowledge and skills necessary to use distance learning in the educational process.

\section{Fourth Domain: Learner}

Table 6: The arithmetic mean and standard deviation of the study sample responses on the fourth domain: the learner (indicators 107: 93).

\begin{tabular}{|c|c|c|c|c|}
\hline No. & Indicator Text & AM & SD & $\begin{array}{l}\text { Degree of } \\
\text { availability of the } \\
\text { indicator }\end{array}$ \\
\hline 93 & $\begin{array}{l}\text { 4-1-1-4 The learner uses the evaluation tools of the } \\
\text { distance learning system. }\end{array}$ & 2.44 & 660. & Weak \\
\hline 94 & $\begin{array}{l}\text { 4-1-1-2 The learner identifies the characteristics of the } \\
\text { technological research tools associated with distance } \\
\text { learning. }\end{array}$ & 2.31 & 540. & Weak \\
\hline 95 & $\begin{array}{l}\text { 4-3-2-2 The learner differentiates between the pros and } \\
\text { cons of communication in the distance learning system. }\end{array}$ & 2.29 & 762. & Weak \\
\hline 96 & $\begin{array}{l}\text { 4-2-1-3 The learner uses research skills in the distance } \\
\text { learning system. }\end{array}$ & 2.25 & 517. & Weak \\
\hline 97 & $\begin{array}{l}\text { 4-2-2-1 The learner verifies the accuracy of the } \\
\text { information obtained. }\end{array}$ & 2.22 & 498. & Weak \\
\hline 98 & $\begin{array}{l}4-2-2-2 \text { The learner uses the information obtained in the } \\
\text { learning process. }\end{array}$ & 2.16 & 462. & Weak \\
\hline 99 & $\begin{array}{l}\text { 4-3-1-1 The learner knows the intellectual property } \\
\text { laws. }\end{array}$ & 2.07 & 378. & Weak \\
\hline 100 & $\begin{array}{l}\text { 4-3-1-2 The learner shall abide by the intellectual } \\
\text { property laws related to the distance learning system. }\end{array}$ & 1.98 & 360. & Weak \\
\hline 101 & $\begin{array}{l}4-2-1-1 \text { The learner knows the technological research } \\
\text { tools. }\end{array}$ & 1.96 & 508. & Weak \\
\hline 102 & $\begin{array}{l}\text { 4-1-2-1 The learner uses various tools in interacting } \\
\text { with the faculty member. }\end{array}$ & 1.96 & 576. & Weak \\
\hline 103 & $\begin{array}{l}\text { 4-3-2-1 The learner adheres to the rules of ethical } \\
\text { behavior. }\end{array}$ & 1.95 & 488. & Weak \\
\hline 104 & $\begin{array}{l}\text { 4-1-1-3 The learner can use the distance learning system } \\
\text { operating programs. }\end{array}$ & 1.89 & 497. & Weak \\
\hline 105 & $\begin{array}{l}\text { 4-1-1-2 The learner defines the characteristics of } \\
\text { distance learning. }\end{array}$ & 1.89 & 416. & Weak \\
\hline 106 & 4-1-2-2 The learner exchanges content with students. & 1.60 & 710. & Very weak \\
\hline 107 & $\begin{array}{l}\text { 4-1-1-1 The learner knows the basic terminology of the } \\
\text { distance learning system. }\end{array}$ & 1.42 & 599. & Very weak \\
\hline
\end{tabular}

The results of Table (6) indicate a weakness in the learner's ability to interact with the distance learning system and use the information and communication technology of the distance learning system, as the response's mean of the sample members ranges between (2.44) and (1.89). Also, the indicator's score is ranked (106) and regarded as very weak, with a mean of (1.60), and the indicator's score is (107) which is considered very weak with a mean of (1.42). 
Fifth Domain: Evaluation

Table 7: The arithmetic mean and standard deviation of the study sample responses on the fifth domain: evaluation (indicators 129: 108).

\begin{tabular}{|c|c|c|c|c|}
\hline No. & Indicator Text & $\mathbf{A M}$ & SD & $\begin{array}{l}\text { Degree } \\
\text { availability } \\
\text { the indicator }\end{array}$ \\
\hline 108 & $\begin{array}{l}\text { 5-2-2-3 The results of the evaluation will } \\
\text { appear for students (talented, outstanding, } \\
\text { and weak). }\end{array}$ & 2.69 & 466. & Medium \\
\hline 109 & $\begin{array}{l}5-2-3-4 \text { The university prepares a feedback } \\
\text { on the evaluation processes. }\end{array}$ & 2.56 & 570. & Weak \\
\hline 110 & $\begin{array}{l}5-2-1-7 \text { The evaluation process is } \\
\text { continuous. }\end{array}$ & 2.55 & 571. & Weak \\
\hline 111 & $\begin{array}{l}\text { 5-1-1-1 The university is committed to } \\
\text { evaluating all processes of the e-learning } \\
\text { system. }\end{array}$ & 2.33 & 771. & Weak \\
\hline 112 & 5.2.1.6 The evaluation process is objective. & 2.33 & 840. & Weak \\
\hline 113 & $\begin{array}{l}5-2-1-5 \text { The university provides assessment } \\
\text { tools for learners. }\end{array}$ & 2.25 & 517. & Weak \\
\hline 114 & $\begin{array}{l}5-2-1-1 \text { The institution shall set specific } \\
\text { standards for evaluation. }\end{array}$ & 2.16 & 501. & Weak \\
\hline 115 & $\begin{array}{l}\text { 5-2-2-1 The university provides data on } \\
\text { evaluation processes. }\end{array}$ & 2.15 & 448. & Weak \\
\hline 116 & $\begin{array}{l}5-1-1-2 \text { The university shall involve all } \\
\text { stakeholders in the evaluation process. }\end{array}$ & 2.04 & 543. & Weak \\
\hline 117 & $\begin{array}{l}\text { 5-1-2-4 The university announces the } \\
\text { evaluation results to the concerned parties } \\
\text { (students - parents). }\end{array}$ & 2.00 & 509. & Weak \\
\hline 118 & $\begin{array}{l}5-2-3-1 \text { The university sets up mechanisms } \\
\text { to follow up the evaluation. }\end{array}$ & 1.98 & 913. & Weak \\
\hline 119 & $\begin{array}{l}5-1-2-3 \text { The university is keen to document } \\
\text { the evaluation processes. }\end{array}$ & 1.96 & 543. & Weak \\
\hline 120 & 5-2-3-3 The university evaluation process. & 1.91 & 398. & Weak \\
\hline 121 & $\begin{array}{l}5-1-2-1 \text { The university sets standards for } \\
\text { evaluation processes. }\end{array}$ & 1.91 & 586. & Weak \\
\hline 122 & $\begin{array}{l}5-2-1-2 \text { The university verifies the validity } \\
\text { of the evaluation tools. }\end{array}$ & 1.85 & 524. & Weak \\
\hline 123 & $\begin{array}{l}5-2-1.8 \text { The evaluation process includes the } \\
\text { targeted learning outcomes. }\end{array}$ & 1.82 & 796. & Weak \\
\hline 124 & $\begin{array}{l}5-1-1-3 \text { The university determines the } \\
\text { mechanisms for implementing evaluation } \\
\text { processes for the distance learning system. }\end{array}$ & 1.80 & 487. & Very weak \\
\hline 125 & $\begin{array}{l}\text { 5-1-1-1 The university is committed to } \\
\text { evaluate all distance learning system } \\
\text { operations. }\end{array}$ & 1.80 & 558. & Very weak \\
\hline 126 & $\begin{array}{l}5-2-1-3 \text { The university checks the stability of } \\
\text { the evaluation tools. }\end{array}$ & 1.71 & 685. & Very weak \\
\hline 127 & $\begin{array}{l}5-2-2-2 \text { The university handles evaluation } \\
\text { process data statistically. }\end{array}$ & 1.47 & 573. & Very weak \\
\hline 128 & $\begin{array}{l}5-1-2-2 \text { The evaluation process is } \\
\text { transparent. }\end{array}$ & 1.45 & 603. & Very weak \\
\hline 129 & $\begin{array}{l}5-2-3-2 \text { The university provides } \\
\text { improvement programs and plans for } \\
\text { learners in light of the evaluation results }\end{array}$ & 1.36 & 557. & Very weak \\
\hline
\end{tabular}

The results of Table (7) for the indicator specified in the ranking (108) that the evaluation results for students (talented, outstanding, weak) are shown with a medium degree, where the response's mean of the 
sample members are (2.69). However, the results for the indicators specified in the ranking (109:123) to the university's weak provision of appropriate evaluation tools for the education and e-learning system that enables it to identify strengths for strengthening and identifying weaknesses to develop proposals for improvement. Thus, the second question of the study, which reads "What is the reality of using distance learning in Higher education institutions?", is answered.

\section{Discussion}

The previous results in the first and second domains illustrate the weakness of the technological infrastructure necessary to transfer the electronic content to learners, the weakness of adequate technical support, the lack of mechanisms to support the technological infrastructure, and the lack of modernization. Precisely, this is due to the lack of qualified human resources to follow the technological infrastructure equipment in higher education institutions, the educational designer's lack of commitment to the developmental characteristics of learners when determining the educational content, the lack of a clear definition of the specifications of the electronic content display appropriate to the developmental characteristics of learners, and the lack of production of distance learning system resources.

Notably, the results of the current study are in agreement with the results of the study (Fojtik, 2018), which confirms the existence of deficiencies in the design of software and multi-educational media necessary for distance learning. It is also in line with the study (Basilaia \& Kvavadze, 2020), which confirms the lack of providing electronic courses and basic electronic content elements necessary to implement distance learning. Accurately, the results in the third domain are due to the scarcity of the faculty member's identification of students' needs in the distance learning system, the lack of design by the faculty member of the strategies and activities of the distance learning system, and the lack of faculty members preparing an appropriate electronic environment that takes into account the targeted learning outcomes. The study's results are consistent with the study (Rashidi, 2020), which confirms the absence of a clear and specific role for a faculty member in distance learning, and a deficiency in providing the necessary software to prepare electronic lessons and tests.

Besides, the results in the fourth and fifth domain are due to the lack of interest of the faculty member in developing these skills among students and evaluating them, the poor knowledge of the learner in the regulations of using the distance learning system, and the weakness of providing appropriate evaluation tools for the distance learning system. The results of the study agree with (Basilaia \& Kvavadze, 2020) and the study (KLimova, 2015), which confirm weak students' skills in using educational websites on the Internet, poor communication with faculty members through e-mail. Also, the study (Vimbi, 2018) indicates that programs based on distance learning may be difficult to implement in laboratory sciences and scientific colleges and the weakness of the faculty member's ability to conduct electronic tests.

\section{Recommendation}

In light of the study's procedures, statement of the problem, and its findings, the study recommends applying the distance learning use's standards to improve their use in university learning, developing faculty members to integrate technology in education to select the distance learning and take advantage of educational and elearning resources available on the Internet, and paying attention to the infrastructure of higher education institutions to provide them with modern computer laboratories connected to the Internet.

\section{Acknowledgment}

The authors are grateful to the Middle East University, Amman, Jordan for the financial support granted to cover the publication fee of this research article.

\section{References}

[1]. Anderson, R.M., Heesterbeek, H., Klinkenberg, D., Hollingsworth, T.D. (2020. How will countrybased mitigation measures influence the course of the COVID-19 pandemic? Lancet 395 (10228), 931934.DOI: https://doi.org/10.1016/S0140-6736 (20)30567-5.

[2]. Basilaia, G., Dgebuadze, M., Kantaria, M., \& Chokhonelidze, G. (2020). Replacing the classic learning form at universities as an immediate response to the COVID-19 virus infection in Georgia. International Journal for Research in Applied Science \& Engineering Technology, 8 (3), 16-40. DOI: 10.22214/ijraset.2020.3021.

[3]. Basilaia, Giorgi \& Kvavadze, David. (2020). Transition to Online Education in Schools during a SARS-COV-2 Coronavirus (COVID-19) Pandemic in Georgia, Pedagogical Research, 5(4) 2-9. DOI: $10.29333 / \mathrm{pr} / 7937$. 
[4]. Dun and Bradstreet Report. (2020). COVID-19 pandemic's severe demand shock for the Indian economy. Retrieved from https://economictimes.indiatimes.com.

[5]. Essaid El Bachari1, El Hassan Abdelwahed and Mohammed El Adnani. (2011). E-learning personalization based on dynamic learners' preference. International Journal of Computer Science \& Information Technology (IJCSIT). 3(3), 200-216. DOI: 10.5121/ijcsit.2011.3314.

[6]. Fojtik, Rostislav. (2018). Problems of distance education: International Journal of Information and Communication Technologies in Education 7(1):14-23. DOI: 10.2478/ijicte-2018-0002.

[7]. Hui, D. S., Azhar, E. I., Madani, T. A., Ntoumi, F. Kock, R., Dar, O., et al. (2020). The continuing 2019-nCoV pandemic threat of novel coronaviruses to global health. The latest 2019 novel coronavirus outbreak in Wuhan, China. International Journal of Infectious Diseases, 91, 264-6.

[8]. DOI: 10.1016/j.ijid.2020.01.009.

[9]. Klimova Frydrychova. B. (2015). Teaching and learning enhanced by information and communication technologies. 5th World Conference on Learning, Teaching and Educational Leadership, WCLTA 2014, Procedia-Social and Behavioral Sciences. V186, 2015, ISSN 1877-0428.

[10]. DOI: 10.1016/j.sbspro.2015.04.112

[11]. McPhee, Tor Söderström. (2012) Distance, online and campus higher education: reflections on learning outcomes, Campus-Wide Information Systems, Vol. 29 ISS: 3 pp. 144 - 155 . DOI: $10.1108 / 10650741211243166$.

[12]. O’Sullivan, D., Krewer, F., and Frank, G., 2017. Technology-enhanced collaborative learning using a project-based learning management system. International Journal of Technology Enhanced Learning, 9(1), 14-36.

[13]. DOI:10.1504/IJTEL.2017.10004161

[14]. Rani Molla, Vox. (2020). Microsoft, Google, and Zoom are trying to Keep up with the demand for their now free work-from-home software. Retrieved on 4 June 2020 from

[15]. https://www.vox.com/recode/2020/3/11/21173449/microsoft-google-zoom-slack-increased-demandfree-work-from-home-software.

[16]. Rao, Sudheendra NR. (2011). Global e-learning: A phenomenological study, Colorado State University.

[17]. Rieley, J. B. (2020). Corona Virus and its impact on higher education. Research Gate.

[18]. Singh, V., \& Thurman, A. (2019). How many ways can we define online learning? A systematic literature review of definitions of online learning (1988-2018). American Journal of Distance Education, 33(4), 289-306. https://doi.org/10.1080/08923647.2019.1663082.

[19]. Tran, Truing; Hoang, Anh-Duc; Nguyen, Yen-Chi; Nguyen, Linh-Chi; Ta, Ngoc-Thuy; Pham, QuangHong; Pham, Chung-Xuan; Le, Quynh-Anh; Dinah, Viet-Hung; Nguyen, Tien-Truing. (2020). toward sustainable learning during school suspension: Socioeconomic, occupational aspirations, and learning behavior of Vietnamese students during COVID-19. Https://search.bvsalud.org/global-literature-onnovel-coronavirus-2019ncov/resourcelen/covidwho-324628

[20]. Vimbi Petrus Mahlangu. (2018). The Good, the Bad, and the Ugly of Distance Learning in Higher Education, in tech Open. DOI: 10.5772/intechopen.75702.

[21]. Visande, J. (2014). Developing critical thinking skills among education students through, informative formative education. International Journal for Cross-Disciplinary Subjects in Education (IJCDSE), 5(4), 1783-1789. ID: 53460774

[22]. nay, M., Newvine, T.n(2006). Perception of distance learning: a comparison of online and traditional learning, journal of online learning and teaching. 2005. ISSN 1558-9528. DOI: 10.28945/243.

[23]. Warrier,b. (2006). Brining about a blend of e-learning and traditional methods. Article in an online edition of India's national newspaper, Mandy, 15.2006.

[24]. Wenham, C., Smith, J., Morgan, R., 2020. COVID-19: The gendered impacts of the outbreak. Lancet 395 (10227), 846-848. DOI: 10.1016/S0140-6736(20)30526-2. 